\title{
Intraspecific genetic variation of striped red mullet (Mullus surmuletus L.) in the Mediterranean Sea assessed by allozyme and random amplified polymorphic DNA (RAPD) analysis
}

\author{
ZISSIS MAMURIS* $\uparrow$, COSTAS STAMATIS $\uparrow \&$ COSTAS TRIANTAPHYLLIDIS $\ddagger$ \\ $\dagger$ Department of Applied and Theoretical Sciences, University of Thessaly, Pedion Areos 38334, \\ Volos and $₫$ Department of Genetics, Development and Molecular Biology, School of Biology, \\ Aristotle University of Thessaloniki, 54006, Thessaloniki, Macedonia, Greece
}

\begin{abstract}
Allozyme analysis on 20 putative enzyme-coding loci and RAPD analysis on 154 markers, amplified by eight decamer random primers, were used to assess the genetic variation of striped red mullet, Mullus surmuletus L., collected from six locations in the Mediterranean Sea. Both methods were able to detect a high degree of genetic polymorphism. For both methods, estimates of variance of allele frequencies $\left(F_{\mathrm{ST}}\right)$, and $\chi^{2}$ analyses, revealed significant differences $(P<0.05)$ among samples. Nei's genetic distance $(D)$ among samples was low (mean $D=0.011$ for allozymes; mean $D=0.018$ for RAPDs) with data from both approaches revealing the sample from France to be most distinct from the Greek samples. Nevertheless, although most of the genetic variation in allozymes was not correlated with geographical distance, a correlation between genetic affinities and geographical area was found with RAPDs. It seems therefore that the RAPD method showed a more pronounced effect of isolation-by-distance in comparison with allozymes, probably because of the different number of markers of the red mullet genome examined with each method. Overall, the RAPD technique can be introduced as a complementary tool in the population genetics of marine fishes, providing supplementary information in their genetic stock structure analysis.
\end{abstract}

Keywords: allozymes, genetic variation, Mediterranean Sea, Mullus surmuletus, RAPDs.

\section{Introduction}

Striped red mullet (Mullus surmuletus L.) ranks among the most commercially important demersal fish, with a total catch of $3320 \mathrm{t}$ in 1994 , representing about $2 \%$ of the total Greek marine catch (Stergiou et al., 1997). Because of its economic importance, considerable research has been devoted to the study of its biology and fisheries in Greek waters with regard to reproduction, ethology and growth (for a review see Stergiou et al., 1997). However, knowledge of its genetic population structure is lacking, although this could provide important information for effective fishery management (Carvalho \& Hauser, 1994). The few studies of allozyme variation of striped red mullet have focused mainly on finding allozymic diagnostic loci between $M$. barbatus

*Correspondence. E-mail: zmamur@uth.gr and $M$. surmuletus and they have been limited to relatively small sample sizes (Cammarata et al., 1991; Mamuris et al., 1998a).

The relative usefulness of different methods in the assessment of intraspecific genetic variation depends largely upon the species and geographical scale to which they are applied, as well as the questions asked (Ward \& Grewe, 1994). Since the 1970s, starch gel protein electrophoresis has been the most common method employed to assay genetic variation within and among populations of many marine teleosts, providing extremely useful information for management and conservation problems (Utter, 1991; Carvalho \& Hauser, 1994; Ward \& Grewe, 1994). However, the relative lack of physical barriers in marine systems results in little intraspecific genetic divergence (Avise, 1989; Ward et al., 1994). On the other hand, there is increasing evidence that the random amplified polymorphic DNA (RAPD) method (Welsh \& McClelland, 1990; Williams 
et al., 1990) can detect nuclear DNA variation in fishes, between subspecies, or populations of the same species (Bardakci \& Skibinski, 1994; Naish et al., 1995; Bielawski \& Pumo, 1997; Mamuris et al., 1998b).

We report here an estimate of the degree of genetic differentiation among samples of $M$. surmuletus taken from five locations of the eastern Mediterranean and one from the western Mediterranean (France) as revealed using allozymes and RAPD markers. Furthermore, we compare the results obtained from the application of these two approaches to the same samples.

\section{Materials and methods}

\section{Samples}

A total of 342 striped red mullet specimens were collected using commercial trawlers at five locations in Greek waters, three from the Aegean Sea (Trikeri1, $n=40$; Trikeri2, $n=41$; Kavala, $n=43$; Rhodes, $n=44$ ) and two from the Ionian Sea (Preveza1, $n=45$; Preveza2, $n=40$; Corfu, $n=49)$ and one in French waters (Gulf of Lion, $n=40$ ) (Fig. 1). To examine the extent of temporal variation in allele frequencies between samples, specimens from Trikeri and Preveza were taken at two different times of the year (Fig. 1). Samples of white

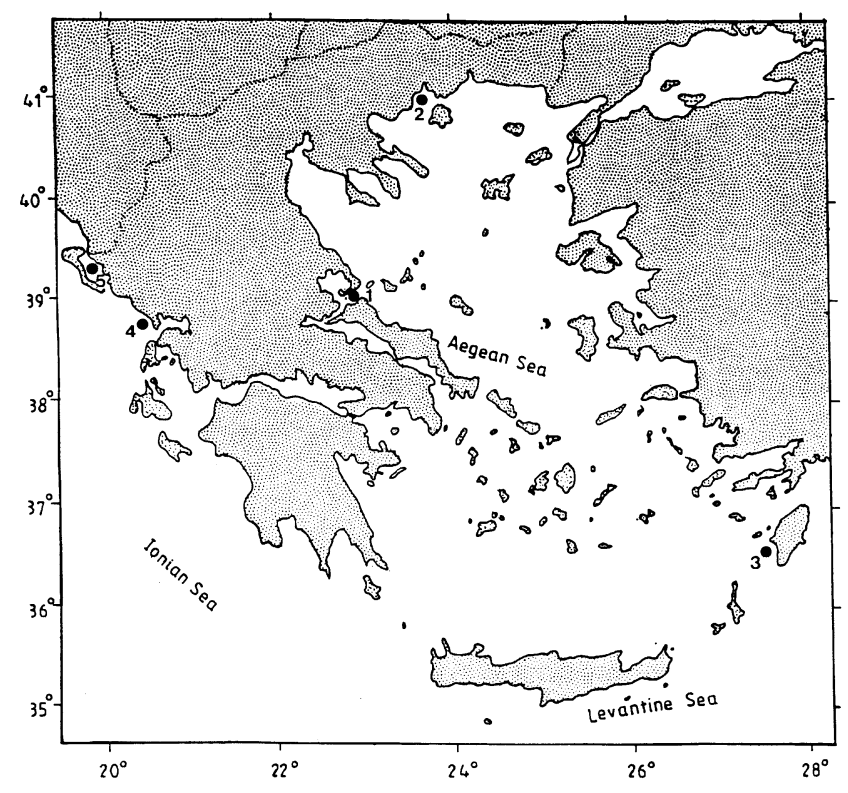

Fig. 1 Map of the eastern Mediterranean showing sampling sites of Mullus surmuletus. 1, Trikeril (TR1; 11/96) and Trikeri2 (TR2; 3/97); 2, Kavala (KAV; 3/97); 3, Rhodes (RHO; 10/97); 4, Prevezal (PR1; 5/96) and Preveza2 (PR2; 12/97); 5, Corfu $(C O R ; 12 / 97)$. The sample from the Gulf of Lion (France) $(F R A ; 12 / 96)$ is not indicated. muscle, liver and eye were removed from individuals and stored at $-40^{\circ} \mathrm{C}$ until further treatment.

\section{Allozyme analysis}

Analysis was carried out employing standard horizontal starch-gel electrophoresis. Sixteen enzymic systems coding for a total of 20 putative loci $\left(A D H^{*}, m A A T\right.$ $1^{*}, \quad s A A T-1^{*}, \quad s A A T-2^{*}, C K-1^{*}, C K-2^{*}, E S T-1^{*}$, $\alpha \mathrm{GPD}^{*}, I D H^{*}, L D H-A^{*}, L D H-B^{*}, M D H^{*}, P G M^{*}$, $P G D H^{*}, P G I-1^{*}, P G I-2^{*}, P G I-3^{*}, S O D^{*}, X D H^{*}$ and $\left.X O^{*}\right)$ were analysed. Details of the enzymes surveyed, the electrophoretic conditions, the stains used and the statistical analysis are given in Mamuris et al. (1998a).

Allele frequencies were calculated for each locus in each population. Genetic variability was estimated using a set of parameters including the mean number of alleles per locus, the percentage of polymorphic loci and the observed and the expected heterozygosity based on Hardy-Weinberg assumptions. Polymorphic loci were tested for conformity to Hardy-Weinberg expectations using $\chi^{2}$-tests and by testing the significance of Wright's fixation index, $F_{\mathrm{IS}}$.

The number of migrants per deme per generation $\left(N_{\mathrm{e}} m\right)$ was calculated from $F_{\mathrm{ST}}$ according to the formula: $N_{\mathrm{e}} m=\left[\left(1 / F_{\mathrm{ST}}\right)-1\right] / 4$ (see Waples, 1987). A dendrogram to illustrate the genetic divergence among the examined populations was constructed from genetic distances using the unweighted pair-group method with arithmetic means (UPGMA; Sneath \& Sokal, 1973). All calculations were performed using BIOSYs Release 1.7 (Swofford \& Selander, 1989).

\section{RAPD analysis}

Forty decamer primers were used during this study, all purchased from Operon Technologies, Alameda, CA, USA, referred to as $\mathrm{A}$ and $\mathrm{F}$ kits, containing 20 random primers each. To assess genetic markers capable of distinguishing between populations, six individuals from each of the eight populations were screened with all the 40 random primers and amplification products were separated on agarose gels. In addition, to determine genetic affinities between populations, 25 individuals from each sample were screened with eight primers (OPA 02, OPA 05, OPA 11, OPA 16, OPF 05, OPF 06, OPF 12 , OPF 17) chosen arbitrarily and the amplification products were separated on nondenaturing polyacrylamide gels. Experimental conditions for the RAPD analysis are documented in Mamuris et al. (1998b).

To calculate $F_{\mathrm{ST}}$ values and genetic distances between populations, the method proposed by Lynch \& Milligan (1994) was applied. Differences in marker frequencies between samples were assessed using $\chi^{2}$ contingency 
table analysis for each variable locus. The degree of geographical heterogeneity of RAPD marker frequencies was checked using a $\chi^{2}$ statistic as described by Roff $\&$ Bentzen (1989). The significance level was obtained by 10000 Monte Carlo randomizations, using the REAP package (McElroy et al., 1991). Genetic distances, calculated for data from all eight primers, were used to estimate genetic affinities between populations using the unweighted pair-group method of analysis (UPGMA) and confidence statements on branches were estimated (Sneath \& Sokal, 1973). Dendrograms were constructed using the PHYLIP 3.5 computer package (Felsenstein, 1993).

\section{Results}

\section{Allozyme analysis}

All enzyme loci produced well-resolved staining patterns consistent with known enzyme subunit structure for all individuals of $M$. surmuletus. Of the 20 loci assayed, 11 loci were monomorphic (mAAT-1*,CK-1*,CK-2*, $L D H-A^{*}, L D H-B^{*}, M D H^{*}, P G I-1^{*}, P G I-2^{*}, P G I-3^{*}$, $P G M^{*}$ and $\left.S O D^{*}\right)$ and the remaining nine loci were polymorphic in at least one population (Table 1).

The mean number of alleles per locus was 1.9, and the percentage of polymorphic loci was $40 \%$ under the 0.99 criterion. The values of observed heterozygosity $\left(H_{\mathrm{o}}\right)$ ranged from 0.167 to 0.228 (mean $H_{\mathrm{o}}=0.194$ ) and of the expected heterozygosity $\left(H_{\mathrm{e}}\right)$ from 0.199 to 0.231 (mean $\left.H_{\mathrm{e}}=0.213\right)$ (Table 1$)$. Two out of 64 tests $(3.125 \%)$ of genotypic fit with Hardy-Weinberg predictions showed significant departures from Hardy-Weinberg proportions after Bonferroni corrections. These two deviations were cause by heterozygote deficiencies and occurred at the $I D H^{*}$ locus in the Rhodes and Prevezal populations.

The $\chi^{2}$ contingency analyses, after Bonferroni corrections, indicated that allele frequencies differed significantly $(P<0.05)$ among the eight samples for seven out of the nine polymorphic loci (s $A A T-1^{*}, E S T^{*}, I D H^{*}$, $P G D H^{*}, \alpha \mathrm{GPD}^{*}, X D H^{*}$ and $\left.X O^{*}\right)$ and also when all loci were considered together (Table 2). The most striking allelic differences occurred between the French and the Greek populations, in particular at the $S A A T 1^{*}$, $P G D H^{*}$ and $X O^{*}$ loci (Table 1). Omitting the French population reduced the number of polymorphic loci by one. However, the same tests were again significant for the remaining Greek samples. Chi-squared comparisons among populations within basins revealed significant $(P<0.05)$ genetic heterogeneity among the three Ionian Sea populations for two loci $\left(I D H^{*}\right.$ and $\left.\alpha G P D^{*}\right)$ and when all loci were considered together. Populations from the Aegean Sea differed significantly $(P<0.05)$ at the $A A T-1^{*}, I D H^{*}, P G D H^{*}$ and $X D H^{*}$ loci and also when all loci were considered together. Chi-squared comparisons among populations taken from the same locality (Trikeri and Preveza) at different times revealed significant differences at the $\alpha G P D^{*}$ locus for Trikeril and Trikeri2 and at two loci $\left(I D H^{*}\right.$ and $\left.X O^{*}\right)$ for Preveza1 and Preveza2. Although significant differences in allele frequencies were observed among populations from the different basins, Wright's $F$-statistics showed that most of this variation was among populations, regardless of their geographical distance (variance component $=0.105, \quad F=0.025$ ) and among populations within basins (Aegean Sea, Ionian Sea and Gulf of Lion) (variance component $=0.08, F=0.019$ ), with little differentiation among basins (variance component $=0.025, F=0.006$ ).

The results of the $\chi^{2}$ analyses were consistent with the $F_{\mathrm{ST}}$ values. Thus, the mean $F_{\mathrm{ST}}$ value for all samples was significant $\left(F_{\mathrm{ST}}=0.035, \chi^{2}\right.$-test $\left.P<0.05\right) \quad$ (Table 2). Genetic population subdivision was less evident, but still significant, among the four populations from the Aegean Sea $\left(F_{\mathrm{ST}}=0.026, \chi^{2}\right.$-test, $\left.P<0.05\right)$ and among the three populations from the Ionian Sea $\left(F_{\mathrm{ST}}=0.015\right.$, $\chi^{2}$-test, $\left.P<0.05\right)$.

Nei's (1972) genetic distances $(D)$ between populations were extremely low for any pairwise comparison and ranged from 0.002 to 0.031 with a mean of 0.011 (Table 3). The French population was the most genetically distinct (mean $D=0.018$ ) and this was clearly illustrated in the dendrogram derived from UPGMA cluster analysis (Fig. 2). However, cluster analysis within Greece failed to associate the geographically related samples.

\section{RAPD analysis}

All primers but three (OPA 09, OPF 03 and OPF 19) yielded satisfactory amplification products with all specimens tested. Each primer produced a unique band pattern of amplified DNA. Nevertheless, all primers failed to yield any diagnostic marker that could lead to unambiguous identification of the various $M$. surmuletus geographical populations.

The number of individuals analysed per population and per primer on polyacrylamide gels varied between 20 (Trikeri2) and 24 (Trikeri1), because any inadequate DNA pattern generated, because of unsatisfactory amplification, was excluded from the analysis (Table 4). The number of reproducible and well-resolved bands analysed per primer in all populations ranged from 14 to 22 (Table 4). Of the 154 bands analysed for all the eight random primers, $73(47.4 \%)$ were polymorphic, and the rest were monomorphic, constantly present in all individuals. The $\chi^{2}$ contingency analyses of RAPD marker 
Table 1 Allele frequencies for polymorphic loci and measures of genetic variability for all loci in all samples of Mullus surmuletus. Population abbreviations are as in Fig. 1. A locus is considered polymorphic if the frequency of the most common allele does not exceed 0.99 . $H_{\mathrm{o}}$, observed heterozygosity (direct count); $H_{\mathrm{e}}$, Hardy-Weinberg expected heterozygosity. Values in parentheses are the standard errors

\begin{tabular}{|c|c|c|c|c|c|c|c|c|c|}
\hline Locus & Alleles & TR1 & TR2 & KAV & RHO & PR1 & PR2 & COR & FRA \\
\hline$s A A T-1^{*}$ & $\begin{array}{l}140 \\
120 \\
100\end{array}$ & $\begin{array}{l}0.150 \\
0.213 \\
0.637\end{array}$ & $\begin{array}{l}0.037 \\
0.195 \\
0.768\end{array}$ & $\begin{array}{l}0.035 \\
0.035 \\
0.930\end{array}$ & $\begin{array}{l}0.080 \\
0.102 \\
0.818\end{array}$ & $\begin{array}{l}0.055 \\
0.189 \\
0.756\end{array}$ & $\begin{array}{l}0.050 \\
0.125 \\
0.825\end{array}$ & $\begin{array}{l}0.102 \\
0.194 \\
0.704\end{array}$ & $\begin{array}{l}0.000 \\
0.000 \\
1.000\end{array}$ \\
\hline$s A A T-2^{*}$ & $\begin{array}{l}110 \\
100\end{array}$ & $\begin{array}{l}0.250 \\
0.750\end{array}$ & $\begin{array}{l}0.366 \\
0.634\end{array}$ & $\begin{array}{l}0.372 \\
0.628\end{array}$ & $\begin{array}{l}0.420 \\
0.580\end{array}$ & $\begin{array}{l}0.389 \\
0.611\end{array}$ & $\begin{array}{l}0.450 \\
0.550\end{array}$ & $\begin{array}{l}0.357 \\
0.643\end{array}$ & $\begin{array}{l}0.375 \\
0.625\end{array}$ \\
\hline$A D H^{*}$ & $\begin{array}{l}145 \\
100\end{array}$ & $\begin{array}{l}0.000 \\
1.000\end{array}$ & $\begin{array}{l}0.000 \\
1.000\end{array}$ & $\begin{array}{l}0.000 \\
1.000\end{array}$ & $\begin{array}{l}0.000 \\
1.000\end{array}$ & $\begin{array}{l}0.000 \\
1.000\end{array}$ & $\begin{array}{l}0.000 \\
1.000\end{array}$ & $\begin{array}{l}0.000 \\
1.000\end{array}$ & $\begin{array}{l}0.025 \\
0.975\end{array}$ \\
\hline$E S T^{*}$ & $\begin{array}{l}110 \\
107 \\
100\end{array}$ & $\begin{array}{l}0.162 \\
0.150 \\
0.688\end{array}$ & $\begin{array}{l}0.207 \\
0.220 \\
0.573\end{array}$ & $\begin{array}{l}0.232 \\
0.198 \\
0.570\end{array}$ & $\begin{array}{l}0.261 \\
0.341 \\
0.398\end{array}$ & $\begin{array}{l}0.167 \\
0.377 \\
0.456\end{array}$ & $\begin{array}{l}0.213 \\
0.375 \\
0.412\end{array}$ & $\begin{array}{l}0.173 \\
0.398 \\
0.429\end{array}$ & $\begin{array}{l}0.263 \\
0.350 \\
0.387\end{array}$ \\
\hline$\alpha \mathrm{GPD}^{*}$ & $\begin{array}{r}120 \\
100 \\
70 \\
40\end{array}$ & $\begin{array}{l}0.205 \\
0.474 \\
0.077 \\
0.231\end{array}$ & $\begin{array}{l}0.037 \\
0.585 \\
0.000 \\
0.378\end{array}$ & $\begin{array}{l}0.116 \\
0.512 \\
0.058 \\
0.314\end{array}$ & $\begin{array}{l}0.113 \\
0.500 \\
0.023 \\
0.364\end{array}$ & $\begin{array}{l}0.033 \\
0.622 \\
0.012 \\
0.333\end{array}$ & $\begin{array}{l}0.150 \\
0.438 \\
0.050 \\
0.362\end{array}$ & $\begin{array}{l}0.031 \\
0.561 \\
0.010 \\
0.398\end{array}$ & $\begin{array}{l}0.150 \\
0.512 \\
0.125 \\
0.213\end{array}$ \\
\hline$I D H^{*}$ & $\begin{array}{l}200 \\
140 \\
100\end{array}$ & $\begin{array}{l}0.000 \\
0.025 \\
0.975\end{array}$ & $\begin{array}{l}0.025 \\
0.085 \\
0.890\end{array}$ & $\begin{array}{l}0.046 \\
0.140 \\
0.814\end{array}$ & $\begin{array}{l}0.011 \\
0.239 \\
0.750\end{array}$ & $\begin{array}{l}0.000 \\
0.067 \\
0.933\end{array}$ & $\begin{array}{l}0.062 \\
0.275 \\
0.663\end{array}$ & $\begin{array}{l}0.031 \\
0.153 \\
0.816\end{array}$ & $\begin{array}{l}0.063 \\
0.237 \\
0.700\end{array}$ \\
\hline$P G D H^{*}$ & $\begin{array}{r}140 \\
120 \\
100 \\
80\end{array}$ & $\begin{array}{l}0.025 \\
0.575 \\
0.400 \\
0.000\end{array}$ & $\begin{array}{l}0.037 \\
0.366 \\
0.597 \\
0.000\end{array}$ & $\begin{array}{l}0.140 \\
0.337 \\
0.523 \\
0.000\end{array}$ & $\begin{array}{l}0.170 \\
0.341 \\
0.489 \\
0.000\end{array}$ & $\begin{array}{l}0.111 \\
0.233 \\
0.656 \\
0.000\end{array}$ & $\begin{array}{l}0.162 \\
0.300 \\
0.538 \\
0.000\end{array}$ & $\begin{array}{l}0.082 \\
0.327 \\
0.591 \\
0.000\end{array}$ & $\begin{array}{l}0.312 \\
0.337 \\
0.338 \\
0.013\end{array}$ \\
\hline$X D H^{*}$ & $\begin{array}{l}280 \\
150 \\
125 \\
100\end{array}$ & $\begin{array}{l}0.038 \\
0.362 \\
0.200 \\
0.400\end{array}$ & $\begin{array}{l}0.085 \\
0.232 \\
0.305 \\
0.378\end{array}$ & $\begin{array}{l}0.128 \\
0.360 \\
0.279 \\
0.233\end{array}$ & $\begin{array}{l}0.261 \\
0.251 \\
0.261 \\
0.227\end{array}$ & $\begin{array}{l}0.067 \\
0.211 \\
0.311 \\
0.411\end{array}$ & $\begin{array}{l}0.113 \\
0.338 \\
0.262 \\
0.287\end{array}$ & $\begin{array}{l}0.082 \\
0.255 \\
0.285 \\
0.378\end{array}$ & $\begin{array}{l}0.250 \\
0.450 \\
0.237 \\
0.063\end{array}$ \\
\hline$X O^{*}$ & $\begin{array}{r}110 \\
100 \\
93 \\
60\end{array}$ & $\begin{array}{l}0.150 \\
0.388 \\
0.287 \\
0.175\end{array}$ & $\begin{array}{l}0.171 \\
0.451 \\
0.207 \\
0.171\end{array}$ & $\begin{array}{l}0.279 \\
0.407 \\
0.209 \\
0.105\end{array}$ & $\begin{array}{l}0.307 \\
0.455 \\
0.159 \\
0.080\end{array}$ & $\begin{array}{l}0.198 \\
0.523 \\
0.070 \\
0.209\end{array}$ & $\begin{array}{l}0.387 \\
0.400 \\
0.138 \\
0.075\end{array}$ & $\begin{array}{l}0.235 \\
0.490 \\
0.092 \\
0.184\end{array}$ & $\begin{array}{l}0.500 \\
0.300 \\
0.200 \\
0.000\end{array}$ \\
\hline Mean sample size per locus & 40 & 41 & 43 & 44 & 45 & 40 & 49 & 40 & \\
\hline $\begin{array}{l}\text { Mean no. of alleles } \\
\text { per locus }\end{array}$ & $\begin{array}{l}1.9 \\
(0.3)\end{array}$ & $\begin{array}{l}1.9 \\
(0.3)\end{array}$ & $\begin{array}{c}1.9 \\
(0.3)\end{array}$ & $\begin{array}{l}1.9 \\
(0.3)\end{array}$ & $\begin{array}{l}1.9 \\
(0.3)\end{array}$ & $\begin{array}{l}1.9 \\
(0.3)\end{array}$ & $\begin{array}{l}1.9 \\
(0.3)\end{array}$ & $\begin{array}{c}1.9 \\
(0.3)\end{array}$ & \\
\hline$\%$ Polymorphic loci & 40 & 40 & 40 & 40 & 40 & 40 & 40 & 40 & \\
\hline$H_{\mathrm{o}}$ & $\begin{array}{c}0.167 \\
(0.052)\end{array}$ & $\begin{array}{c}0.195 \\
(0.059)\end{array}$ & $\begin{array}{c}0.170 \\
(0.054)\end{array}$ & $\begin{array}{c}0.207 \\
(0.064)\end{array}$ & $\begin{array}{c}0.205 \\
(0.066)\end{array}$ & $\begin{array}{l}0.228 \\
(0.068)\end{array}$ & $\begin{array}{c}0.215 \\
(0.067)\end{array}$ & $\begin{array}{c}0.172 \\
(0.055)\end{array}$ & \\
\hline$H_{\mathrm{e}}$ & $\begin{array}{l}0.202 \\
(0.064)\end{array}$ & $\begin{array}{c}0.204 \\
(0.062)\end{array}$ & $\begin{array}{c}0.209 \\
(0.065)\end{array}$ & $\begin{array}{l}0.226 \\
(0.067)\end{array}$ & $\begin{array}{c}0.199 \\
(0.061)\end{array}$ & $\begin{array}{l}0.231 \\
(0.067)\end{array}$ & $\begin{array}{c}0.216 \\
(0.063)\end{array}$ & $\begin{array}{l}0.215 \\
(0.067)\end{array}$ & \\
\hline
\end{tabular}

frequencies showed significant heterogeneity for 39 of 73 markers $(53.4 \%)$, using the single-test significance level of 0.05 . However, after Bonferroni corrections, only 18 markers (24.6\%) showed significant heterogeneity $(P<0.05)$. This percentage was reduced to $14.1 \%$ $(10 / 71)$ after the exclusion of the French sample, to $5.7 \%(4 / 70)$ among samples from the Aegean Sea and to $4.8 \%(3 / 70)$ among samples from the Ionian Sea. No significant differences were found between Trikeril and Trikeri2 and between Preveza1 and Preveza2. Furthermore, the frequencies of 10 markers were found to follow a geographical trend in different populations. Overall analysis of marker frequencies, using $\chi^{2}$-tests with a Monte Carlo simulation, showed significant geographical heterogeneity between the eight samples $(P<0.001)$ as well as between basins: Ionian - Aegean

(C) The Genetical Society of Great Britain, Heredity, 83, 30-38. 
Table 2 Chi-squared values and standardized variance $\left(F_{\mathrm{ST}}\right)$ for tests of heterogeneity in allele frequencies (nine loci) among eight Mullus surmuletus samples

\begin{tabular}{lcccr}
\hline Locus & No. of alleles & \multicolumn{1}{c}{$F_{\mathrm{ST}}$} & $\chi^{2}$ & $\mathrm{~d} . \mathrm{f}$. \\
\hline$s A A T-1^{*}$ & 3 & $0.059^{* *}$ & $57.782^{* *}$ & 14 \\
$s A A T-2^{*}$ & 2 & 0.013 & 8.274 & 7 \\
$A D H^{*}$ & 2 & 0.022 & 15.144 & 7 \\
$E S T^{*}$ & 3 & $0.032^{* *}$ & $36.685^{*}$ & 14 \\
$\alpha \mathrm{GPD}^{*}$ & 4 & $0.021^{* *}$ & $69.245^{* *}$ & 21 \\
$I D H^{*}$ & 3 & $0.060^{* *}$ & $52.981^{* *}$ & 14 \\
$P G D^{*}$ & 4 & $0.043^{* *}$ & $73.160^{* *}$ & 21 \\
$X D H^{*}$ & 4 & $0.035^{* *}$ & $76.567^{* *}$ & 21 \\
$X O^{*}$ & 4 & $0.036^{* *}$ & $76.711^{* *}$ & 21 \\
Mean & & $0.035^{* *}$ & & \\
\hline
\end{tabular}

$* P<0.01 ; * P<0.001$.

$(P<0.01)$, Ionian - Gulf of Lion $(P<0.001)$ and Aegean - Gulf of Lion $(P<0.001)$.

The estimated values of heterozygosity were slightly higher for all comparisons between populations (mean $\left.H_{i j}=0.259\right)$ than for those observed within samples (mean $H_{i}=0.245$ ). Estimates of $F_{\mathrm{ST}}$ using the expected heterozygosity values for the eight populations, suggested the presence of subdivision among populations $\left(F_{\mathrm{ST}}=0.053\right)$. This subdivision was more pronounced in Aegean $\left(F_{\mathrm{ST}}=0.033\right)$ than in Ionian Sea $\left(F_{\mathrm{ST}}=0.015\right)$ populations.

Values of pairwise comparisons of Nei's (1972) genetic distance $(D)$ between populations, computed from combined data for the eight primers, ranged from $D=0.007$ to $D=0.037$ (Table 3 ). The French sample was the most genetically distinct (mean $D=0.034$ ) and the Aegean Sea samples seem to diverge from the Ionian Sea samples (mean $D=0.016$ for all pairwise comparisons between the two groups of populations). Genetic differences between populations exhibited a consistent geographical pattern clearly illustrated in the UPGMA dendrogram derived from cluster analysis (Fig. 3).

\section{Discussion}

In the present study, two molecular methods (allozyme and RAPD) were used to determine genetic variation in striped red mullet populations. Because of the dominance property of RAPDs, gene frequency estimates calculated from RAPD data are less accurate than those obtained from codominant markers, such as allozymes. Therefore, two to 10 times more individuals should be sampled per locus and more loci should be scored per individual, in comparison with allozyme analysis (Lynch \& Milligan, 1994). Here, although a smaller number of individuals per locus was screened compared with allozymes (about 25 vs. 40 individuals per population), about eight times more loci (154 vs. 20 loci per individual) were sampled to estimate genetic affinities between populations.

Allozyme analysis revealed nine polymorphic loci (45\%). Alternatively, the RAPD method uncovered 73 reliable polymorphisms (47.4\%) for the eight random primers selected for population analysis. According to allozymes, genotypic proportions differed significantly from Hardy-Weinberg expectations at two out of 64 tests, less than the $5 \%$ of cases which would be expected by chance, indicating that breeding within the eight populations sampled was panmictic. However, given the high value of $F_{\mathrm{ST}}$ found for the $I D H^{*}$ locus (Table 2), one cannot exclude the possibility that the Hardy-Weinberg deviation observed for this locus resulted from a Wahlund effect caused by pooling samples that were not part of the same population. Furthermore, the eight populations were characterized by high levels of heterozygosity, because the mean value for the observed heterozygosity was 0.195 (and the average for all marine teleosts has been estimated as 0.064; Ward et al., 1994). In the absence of recent bottlenecks, organisms such as marine fishes and striped red mullet in particular, with very large populations, are expected to have larger $H$ s (Gyllensten, 1985). The large value of $H$ therefore implies that

Table 3 Nei's (1972) genetic distance $(D)$ between eight populations of Mullus surmuletus based on RAPD (above) and on allozyme (below) analysis

\begin{tabular}{lcccccrrrr}
\hline Population designation & 1 & 2 & 3 & 4 & 5 & 6 & 7 \\
\hline 1 Trikeri1 & - & 0.011 & 0.010 & 0.015 & 0.014 & 0.021 & 0.020 & 0.033 \\
2 Trikeri2 & 0.009 & - & 0.005 & 0.010 & 0.012 & 0.013 & 0.011 & 0.033 \\
3 Kavala & 0.012 & 0.007 & - & 0.008 & 0.016 & 0.016 & 0.015 & 0.033 \\
4 Rhodes & 0.019 & 0.008 & 0.004 & - & 0.020 & 0.019 & 0.019 & 0.031 \\
5 Preveza1 & 0.017 & 0.003 & 0.009 & 0.009 & - & 0.007 & 0.007 & 0.037 \\
6 Preveza2 & 0.021 & 0.010 & 0.005 & 0.002 & 0.010 & - & 0.006 & 0.033 \\
7 Corfu & 0.014 & 0.003 & 0.007 & 0.005 & 0.002 & 0.009 & - & 0.034 \\
8 France & 0.031 & 0.024 & 0.009 & 0.009 & 0.026 & 0.009 & 0.022 & - \\
\hline
\end{tabular}


Fig. 2 UPGMA dendrogram based on Nei's (1972) genetic distance, summarizing the data on differentiation between Mullus surmuletus populations, according to allozyme analysis.

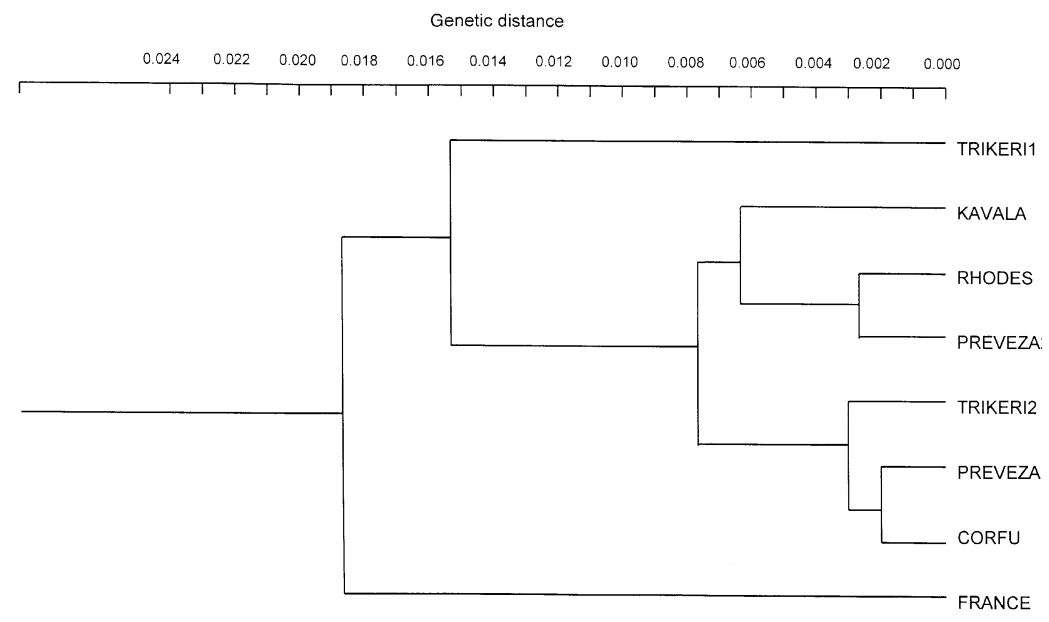

Table 4 Numbers of specimens $(N)$ and RAPD bands $(n)$ analysed per population and per primer and numbers of polymorphic bands $(P)$ found per primer in each population of Mullus surmuletus

\begin{tabular}{|c|c|c|c|c|c|c|c|c|c|c|c|c|c|c|c|c|c|c|c|c|c|c|c|c|}
\hline Population & \multicolumn{3}{|c|}{ OPA 02} & \multicolumn{3}{|c|}{ OPA 05} & \multicolumn{3}{|c|}{ OPA 11} & \multicolumn{3}{|c|}{ OPA 16} & \multicolumn{3}{|c|}{ OPF 05} & \multicolumn{3}{|c|}{ OPF 06} & \multicolumn{3}{|c|}{ OPF 12} & \multicolumn{3}{|c|}{ OPF 17} \\
\hline Trikeri2 & 20 & 20 & 8 & 20 & 20 & 10 & 20 & 14 & 5 & 20 & 22 & 11 & 20 & 21 & 11 & 20 & 19 & 8 & 20 & 16 & 6 & 20 & 22 & 10 \\
\hline Kavala & 21 & 20 & 8 & 21 & 20 & 10 & 21 & 14 & 5 & 21 & 22 & 11 & 21 & 21 & 11 & 21 & 19 & 8 & 21 & 16 & 6 & 21 & 22 & 10 \\
\hline Rhodes & 23 & 20 & 8 & 23 & 20 & 10 & 23 & 14 & 5 & 23 & 22 & 11 & 23 & 21 & 11 & 23 & 19 & 8 & 23 & 16 & 6 & 23 & 22 & 10 \\
\hline Corfu & 22 & 20 & 8 & 22 & 20 & 10 & 22 & 14 & 4 & 22 & 22 & 11 & 22 & 21 & 10 & 22 & 19 & 8 & 22 & 16 & 7 & 22 & 22 & 11 \\
\hline France & 23 & 20 & 8 & 23 & 20 & 10 & 23 & 14 & 6 & 23 & 22 & 11 & 23 & 21 & 11 & 23 & 19 & 8 & 23 & 16 & 6 & 23 & 22 & 11 \\
\hline
\end{tabular}

Fig. 3 UPGMA dendrogram based on Nei's (1972) genetic distance, summarizing the data on differentiation between Mullus surmuletus populations, according to RAPD analysis. Bootstrap estimates (as a percentage) are indicated above branches.

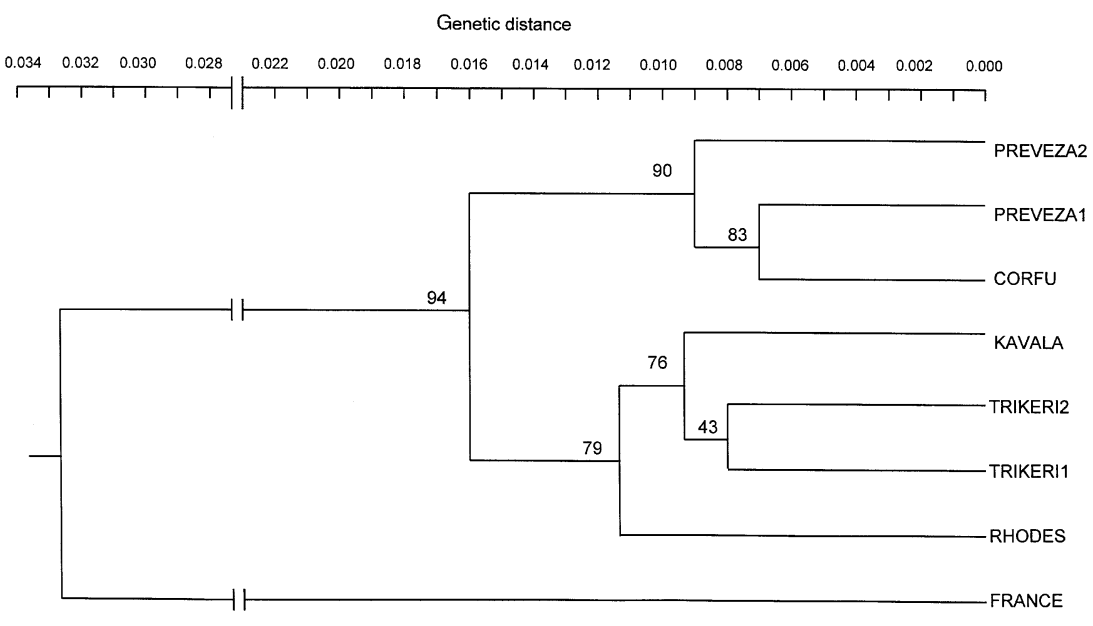

striped red mullet has had a long unbroken history in the Mediterranean Sea without population bottlenecks. Similar results were found for red mullet (Mullus barbatus) (Mamuris et al., 1998a)

Both methods failed to produce specific markers that could discriminate populations, but both were successful in revealing genetic heterogeneity between samples. The $\chi^{2}$ contingency analyses for allozymes revealed significant differences in allelic distribution between samples at seven of the nine polymorphic loci (Table 2). For RAPDs, although only 18 of the 73 markers exhibited statistically significant differences, overall analysis of

(C) The Genetical Society of Great Britain, Heredity, 83, 30-38. 
marker frequencies, based on $\chi^{2}$-tests with a Monte Carlo simulation, suggested genetic subdivision between samples. Within Greece, both methods showed a greater genetic heterogeneity for the Aegean Sea populations compared with those collected from the Ionian Sea. This could be because geographical distances between collecting sites were greater in the Aegean than in the Ionian Sea, thereby implying that a higher level of gene flow occurs between the Ionian Sea populations. This significant genetic heterogeneity between populations was confirmed by $F_{\mathrm{ST}}$ analysis. $F_{\mathrm{ST}}$ values calculated from RAPD data, although higher, were in agreement with those calculated from allozyme data $(0.053$ vs. 0.035 for all samples, 0.033 vs. 0.026 for the Aegean Sea and 0.015 for the Ionian Sea).

Nei's (1972) genetic distances computed using RAPD data (mean $D=0.018$ ) were in general slightly greater than those calculated using allozyme data (mean $D=0.011)$. The two data sets were significantly correlated (Mantel $t$-test; $r=0.63, P<0.01$ ) when all populations were considered together, but the statistical test failed to correlate the data sets for the Greek populations when the French population was excluded from the analysis (Mantel $t$-test; $r=0.32, P=0.052$ ). Both methods agreed that the French population was by far the most genetically distinct (Figs 2 and 3). Nevertheless, genetic heterogeneity between samples within Greek waters was found to be at random in relation to geographical distances between collecting sites when allozymes were used, even for samples collected from the same sites (Mantel $t$-test; $r=0.05, P=0.34$ ) (Fig. 2). This was further supported by hierarchical analysis, which showed greater differentiation between populations than between basins. On the other hand, a clear geographical distance pattern for genetic affinities between samples appeared when RAPDs were applied (Mantel $t$-test; $r=0.72, P<0.01$ ) (Fig. 3).

According to these results, genetic parameters estimated from the two methods were not completely discordant. Probably, the most striking difference between the two methods was the more pronounced effect of isolationby-distance produced by RAPDs in comparison with allozymes. One possible explanation that could account for this result is that the RAPD method was able to screen a larger part of the nuclear genome than allozymes.

The life cycle of striped red mullet includes a pelagic larval phase followed by a benthic adult phase (Stergiou et al., 1997), and larval exchange is assumed to be the major mechanism uniting spatially discrete populations. $F_{\mathrm{ST}}$ values, if significantly different from zero (Ferguson, 1994), may be used to estimate the effective number of migrants per generation $\left(N_{\mathrm{e}} m\right)$ between populations. The estimated $N_{\mathrm{e}} m$ for the populations sampled was 6.9 according to allozymes and 4.5 according to RAPDs.
These values were much smaller than the mean value for marine fishes $\left(N_{\mathrm{e}} m=22.76\right.$; Ward et al., 1994), but they were close to those estimated for other marine species in Mediterranean Sea, such as Engraulis encrasicolus $\left(N_{\mathrm{e}} m=8.6\right.$; Bembo et al., 1996), Mullus barbatus $\left(N_{\mathrm{e}} m=5.6\right.$; Mamuris et al., 1998a) and Mugil cephalus ( $N_{\mathrm{e}} m=7.26$; Rossi et al., 1998). One genetically effective migrant per generation between populations would be sufficient to prevent fixation of an allele. However, significant divergence in allele frequencies between populations can occur with up to 10 migrants per generation (Allendorf \& Phelps, 1981).

These results further support the hypothesis that the oceanographic and bathymetric conditions prevailing in the Aegean and Ionian Seas may reduce gene flow between sampling sites. The Ionian Sea is the deepest sea of the Mediterranean Basin, and depths in excess of 3000-4000 m occur (Theodorou, 1990). Striped red mullet adults are found mainly at depths down to $300 \mathrm{~m}$. Therefore, these bathymetric constraints may limit their large-scale migration between the Aegean and Ionian Seas, given that migration can occur only through two of the three Kitherian Straits: Elafonissos (180 $\mathrm{m}$ deep, $11 \mathrm{~km}$ wide) and Kithira (160 m deep, $33 \mathrm{~km}$ wide). Furthermore, mass transportation of pelagic striped red mullet eggs and larvae between the two seas may also be limited by oceanographic constraints. The circulation of the upper layer water of the Cretan Sea, the Straits of the Western Cretan Arc and the adjacent south-eastern Ionian Sea is determined by the intense anticyclonic gyre south of Greece, the socalled Pelops gyre, and the Mirtoan Western Crete cyclone (Theodorou et al., 1997). The surface circulation in the Ionian Sea shows a distinct division of the flow field in the vicinity of $37^{\circ} 30^{\prime} \mathrm{N}$ latitude. North of the latter, the flow is broadly cyclonic. However, to the south a meso-scale anticyclone occurs, constituting a northernmost extension of the Pelops anticyclone and dominating this part of the study area.

In conclusion, both allozyme and RAPD methods can provide useful genetic information on striped red mullet that could be valuable for stock structure analysis. The advantages and the disadvantages of each technique in the field of population genetics have been extensively documented in several review articles (Hadrys et al., 1992; Carvalho \& Hauser, 1994; Ward \& Grewe, 1994). However, the extent of allozyme variation, especially in marine fishes, may be insufficient to conduct a stock structure analysis. In this case the RAPD method, being able to screen more easily a larger part of the nuclear genome than allozymes, may assess higher levels of intraspecific variation.

The effective use of allozymes in the assessment of genetic variation depends on their selective neutrality. 
Although some allozymic differentiation seems to be determined by locus-specific selection (Utter, 1991), several observations suggest that most allozyme markers are neutral to the approximation needed for making inferences about population structure (Carvalho \& Hauser, 1994). If, however, some allozymes respond to selection pressures, then the use of nonexpressed DNA markers, such as RAPDs, which are less likely to be subject to selection, may facilitate the resolution of genetic intraspecific differentiation. Many authors have highlighted the importance of simultaneous application of different methods in population genetics (Carvalho \& Hauser, 1994; Ward \& Grewe, 1994; Ward et al., 1994). Given that the RAPD technique is less laborious compared with other fingerprinting techniques, producing results with low statistical error (Naish et al., 1995), and that it does not require prior knowledge of DNA sequences (Hadrys et al., 1992), it could be introduced as a complementary tool to estimate genetic affinities at the nuclear level between populations of marine fish species.

\section{Acknowledgements}

We thank A. Triantafyllidis and A. Apostolidis for useful suggestions and S. Krikas for technical assistance. Financial support from the Research Committee of University of Thessaly is gratefully acknowledged.

\section{References}

ALLENDORF, F. W. AND PHELPS, S. R. 1981. Use of allelic frequencies to describe population structure. Can. J. Fish. Aquat. Sci., 38, 1507-1514.

AVISE, J. C. 1989. Gene trees and organismal histories: a phylogenetic approach to population biology. Evolution, 43, 1192-1208.

BARDAKCI, F. AND SKIBINSKI, D. O. F. 1994. The application of the RAPD technique in tilapia fish: species and subspecies identification. Heredity, 73, 117-123.

BEMBO, D. G., CARVALHO, G. R., CINGOLANI, N. AND PITCHER, T. J. 1996. Electrophoretic analysis of stock structure in Northern Mediterranean anchovies, Engraulis encrasicolus. ICES J. Mar. Sci., 53, 115-128.

BIELAWSKI, J. P. AND PUMO, D. E. 1997. Random amplified polymorphic DNA (RAPD) analysis of Atlantic Coast striped bass. Heredity, 78, 32-40.

CAmmarata, M., PARrinello, N. AND ARCUleO, M. 1991. Biochemical taxonomic differentiation between Mullus barbatus and Mullus surmuletus (Pisces, Mullidae). Comp. Biochem. Physiol., 99B, 719-722.

CARVALHO, G. R. AND HAUSER, L. 1994. Molecular genetics and the stock concept in fisheries. Rev. Fish Biol. Fish., 4, 326-350.

FELSENSTEIN, J. 1993. PHYLIP (Phylogeny inference package), Version 3.5c. Department of Genetics, SK-50, University of Washington, Seattle, WA.
FERGUSON, A. 1994. Molecular genetics in fisheries: current and future perspectives. Rev. Fish Biol. Fish., 4, 379-383.

GYLLENSTEN, U. 1985. The genetic structure of fish: Differences in the intraspecific distribution of biochemical genetic variation between marine, anadromous and freshwater species. J. Fish Biol., 26, 691-699.

HADRYS, H., BALICK, M. AND SCHIERWATER, B. 1992. Applications of random amplified polymorphic DNA (RAPD) in molecular ecology. Mol. Ecol., 1, 55-64.

LYNCH, M. AND MILligAN, B. G. 1994. Analysis of population genetic structure with RAPD markers. Mol. Ecol., 3, 91-99.

MAMURIS, Z., APOSTOLIDIS, A. P. AND TRIANTAPHYLLIDIS, C. 1998a. Genetic protein variation in red mullet (Mullus barbatus) and striped red mullet (M. surmuletus) populations from the Mediterranean Sea. Mar. Biol., 130, 353-360.

MAMURIS, Z., APOSTOLIDIS, A. P., THEODOROU, A. J. AND TRIANTAPHYLLIDIS, C. 1998b. Application of random amplified polymorphic DNA (RAPD) markers to evaluate intraspecific genetic variation in red mullet (Mullus barbatus). Mar. Biol., 132, 171-178.

McELROY, D., MORAN, P., BERMINGHAM, E. AND KORNFIELD, J. 1991. REAP: The restriction enzyme analysis package, version 4.0. Department of Zoology, University of Maine, Orono, $\mathrm{ME}$.

NAISH, K. A., WARREN, M., BARDAKCI, F., SKIBINSKI, D. O. F., CARVAlHO, G. R. AND MAIR, G. C. 1995. Multilocus DNA fingerprinting and RAPD reveal similar genetic relationships between strains of Oreochromis niloticus (Pisces: Cichlidae). Mol. Ecol., 4, 271-274.

NEI, M. 1972. Genetic distance between populations. Am. Nat., 106, 283-292.

ROFF, D. A. AND BENTZEN, P. 1989. The statistical analysis of mitochondrial DNA polymorphisms: $\chi^{2}$ and the problem of small samples. Mol. Biol. Evol., 6, 539-545.

Rossi, A. R., CAPUlA, M., CROSETTI, D., SOLA, L. AND CAMPTON, D. E. 1998. Allozyme variation in global populations of striped mullet, Mugil cephalus (Pisces: Mugilidae). Mar. Biol., 131, 203-212.

SNEATH, P. H. A. AND SOKAL, R. R. 1973. Numerical Taxonomy. W. H. Freeman and Co., San Francisco, CA.

STERGiou, K. I., Christou, E. D., GEORGOPOUlOS. D., ZENETOS, A. AND SOUVERMEzoglou, C. 1997. The Hellenic seas: physics, chemistry, biology and fisheries. Ann. Rev. Oceanogr. Mar. Biol., 35, 415-538.

SWOFFORD, D. L. AND SELANDER, R. B. 1989. BIOSYS-I. $A$ computer program for the analysis of allelic variation in population genetics and biochemical systematics. Release 1.7. Illinois Natural History Survey, Champaign, IL.

THEODOROU, A. J. 1990. The extent of the Atlantic water influence in the northeastern Ionian Sea (late winter/early spring 1986). Bollettino Di Oceanologia Teorica Ed Applicata, 8, 237-250.

THEODOROU, A. J., THEOCHARIS, A. AND BALOPOUlOS, E. 1997. Circulation in the Cretan Sea and adjacent regions in late winter 1994. Oceanol. Acta, 20, 585-596.

UTTER, F. M. 1991. Biochemical genetics and fishery management: an historical perspective. J. Fish Biol., 39 (Suppl. A), $1-20$. 
WAPLES, R. 1987. A multispecies approach to the analysis of gene flow in marine shore fishes. Evolution, 41, 385-400.

WARD, R. D. AND GREWE, P. M. 1994. Appraisal of molecular genetic techniques in fisheries. Rev. Fish Biol. Fish., 4, 300-325.

WARD, R. D., WOODWARK, M. AND SKIBINSKI, D. O. F. 1994. A comparison of genetic diversity levels in marine, freshwater, and anadromous fishes. J. Fish Biol., 44, 213-232.
WELSH, J. AND McCLELlAND, M. 1990. Fingerprinting genomes using PCR with arbitrary primers. Nucl. Acids Res., 18, 7213-7218.

WILliAMS, J. G. K., KUBELIK, A. R., LIVAK, K. J., RAFALSKI, J. A. AND TINGEY, S. V. 1990. DNA polymorphisms amplified by arbitrary primers are useful as genetic markers. Nucl. Acids Res., 18, 6531-6535. 